\title{
Collection, conservation, exploitation and development of rice genetic resource of Vietnam
}

\author{
Thu thập, bảo tồn, khai thác và phát triển nguồn gene lúa của Việt Nam \\ Short communication
}

Nguyen, Duc Bach*; Tong, Van Hai; Nguyen, Van Hung; Phan, Huu Ton

Center for Conservation and Development of Crop Genetic Resources (CCD-CGR), Vietnam National University of Agriculture, Ngo Xuan Quang, Trau Quy, Gia Lam, Hanoi, Vietnam

\begin{abstract}
Genetic resources are important for the development of every country and for humanity. Collection, conservation and reasonable utilization of genetic resource is required mission. Understanding the importance of genetic resource, especially rice germplasm, since 2001, Center for conservation and development of crop genetic resources (CCD-CGR) of Hanoi University of Agriculture (Vietnam National University of Agriculture) has been collected, conserved and evaluated rice germplasm from different provinces of Vietnam for breeding programs. So far, 1090 accessions of local rice of Vietnam have been collected. Evaluation of agronomic properties and screening of some important genes using DNA molecular markers have revealed that Vietnamese rice germplasm has high level diversity and containing important genes for quality and resistance for disease and pests. These genetic resources are potential materials for national breeding programs. Based on the collected germplasm, 3 new glutinous rice varieties have been successfully created with high yield and good quality. In addition, the degradation of local rice varieties is also a matter of concern. So far, 4 specialty rice varieties Deo Dang, Ble chau, Pu de and Khau dao have been successfully restored for the north provinces of Vietnam. The main results of this study are germplasms for rice breeding programs and new improved varieties that bring economic benefits to farmers and the country.
\end{abstract}

Nguồn gene là tài nguyên sống còn của mỗi quốc gia và của toàn nhân loại. Vì vậy thu thập, bảo tồn, đánh giá và khai thác hợp lý nguồn tài nguyên này có ý nghĩa rất lớn. Nhận thức được tầm quan trọng của nguồn gen nhất là nguồn gen cây lúa, ngay tù đầu nhũ̃ng năm 2000, Trung tâm bảo tồn và phát triển nguồn gene cây trồng thuộc Truờng Đại học nông nghiệp, nay là Học Viện nông nghiệp Việt Nam đã tiến hành thu thập, lưu giũu, đánh giá và khai thác nguồn gene lúa. Kết quả đã thu thập, luu giư được 1090 mẫu giống lúa địa phương Việt Nam. Đánh giá đặc điểm nông sinh học và phát hiện một số gene quy định các tính trạng chất lượng và kháng sâu bệnh bằng chỉ thị phân tử DNA. Đây là nguồn gene quan trọng cho chọn tạo giống. Dựa vào nguồn gene thu thập được, cho đến nay, Trung tâm bảo tồn và phát triển nguồn gene cây trồng đã lai và chọn tạo được thành công 03 giống lúa nếp chất luợng cao. Ngoài ra, thoái hóa giống cũng là vấn đề đang được quan tâm. Cho đến nay 4 giống lúa đặc sản Đèo đàng, Ble châu, Pu đe và Khẩu dao đã đuợc phuc tráng và đưa vào sản xuất. Kết quả của nhũng nghiên cứu này là ngân hàng các giống lúa làm nguồn gene để chọn tạo giống mói đem lại lọi ích kinh tế cho người nông dân và đất nước.

Keywords: Genetic resources, rice breeding, resistance gene, rice varieties, rice germplasm

\section{Introduction}

Vietnam located in the hotspot region with high level of biodiversity and ecological habitats. Over 4000 thousand years of rice cultivation, Vietnam has a great diversity of rice varieties (Nguyen Van Bo, 2002., Nguyen Thi Ngoc Hue, et al., 2007, Nguyen Thi Lang, et al., 2010). In high land areas, due to difference in habits, climates and ability to approach modern techniques, local people of Vietnam, still maintain and cultivate local rice varieties. These 
varieties have a high level of genetic diversity (Thuy $\mathrm{T}$. T., et al., 2012). In Vietnam recently, rapid development and urbanization in many areas have changed the cultivation habits of local farmers. New improved rice varieties from different sources are introduced and widely used because of their high productivity. The consequence of this process is the loss of traditional rice varieties that have existed for years. Therefore, after sometimes, the richness and diversity of local rice varieties is significantly reduced. In addition, the industrialization, tourist activities and services are also important factors leading to the rapid erosion of genetic resources (M. Nakagahra, et al., 2000). This is a warning bell for long term and sustainable development of agriculture in Vietnam (Nguyen Thi Ngoc Hue, et al, 2007; Nguyen Thi Lang, et al., 2010).

It is very necessary to mention that the local rice varieties carry valuable properties such as high quality, fragrant, tolerance under stress and resistance to wide range of diseases and pests. These properties of these varieties are the results of thousands years of evolution and adaptation.

For breeding new improved rice varieties with high productivity, quality, resistance to diseases, the genetic resources are indispensable materials. Therefore, it is necessary to have a long-term vision and strategies for the collection, preservation, evaluation and utilization of these genetic resources (Denning, et al., 1994).

\section{Objectives and research activities}

\subsection{Objectives}

The objectives of this study are collection, conservation, evaluation and utilization activities of rice genetic resources from local areas of Vietnam.

\subsection{Research activities}

Since 2001, many investigations of the distribution of rice varieties have been carried out throughout the country. The main targets are high land areas in the north where many ethnic groups and minor people are living. So far, 1090 rice varieties have been collected and conserved in (CCD-CGR). For ten years, evaluation of these genetic resources has been carried out. Main important agronomic properties and traits such as glutinous rice, regular rice, type (Japonica, Indica, Javanica), light reaction, growth duration (short, medium and long) were evaluated. The presence of genes for good quality and resistance traits in accessions was discovered by using DNA markers. The output data were stored as accessible information for the purposes of rice breeding. In addition, strategies for the conservation of rice genetic resource to 2020 were established.

\section{Results and discussion}

\subsection{Collection of rice genetic resources}

Since 2001, investigation and collection of rice varieties have been carried out in almost all provinces in North, some provinces in the centre and the south of Vietnam where many ethnic minorities live. It is very necessary because many local rice varieties kept by these people would be lost or degeneration. Since 2001, 1090 accessions have been collected and conserved (Table 1) in CCD-CGR of Vietnam National University of Agriculture (Figure 1).

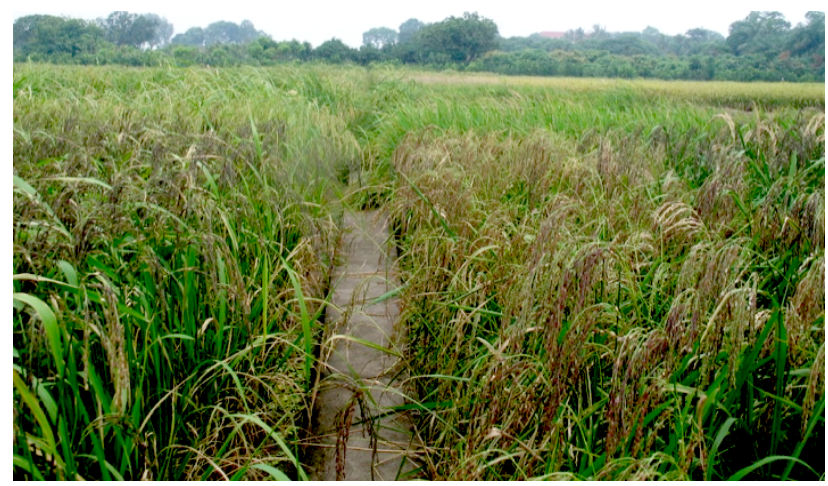

Figure 1. Ex situ conservation of local rice varieties in CCD-CGR, National University of Agriculture

Among 1090 accessions, the number of samples collected in Lao Cai and Son La provinces were 254 and 232, respectively. It should be mentioned that there was a strong relation between the diversity of samples collected and the number of ethnic groups in the mountain regions. All collected samples were classified and encrypted in databases as germplasms for evaluation and exploitation (Figure 2).

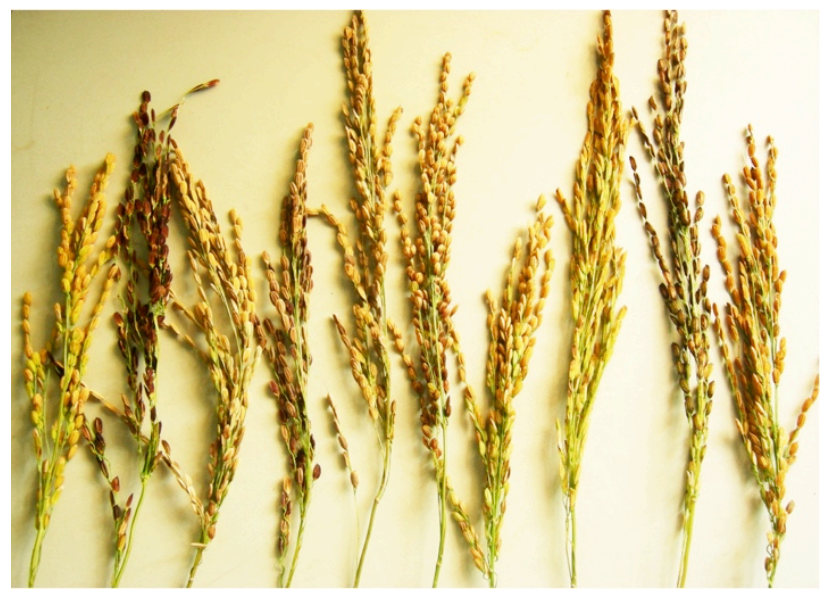

Figure 2. Local glutinous rice varieties collected from north provinces of Vietnam 
Table 1. Number of rice samples collected from 2001 to 2011

\begin{tabular}{|c|c|c|c|c|c|c|c|c|c|c|c|c|}
\hline $\begin{array}{l}\text { Year / } \\
\text { Provinces }\end{array}$ & 2001 & 2002 & 2003 & 2004 & 2005 & 2006 & 2007 & 2008 & 2009 & 2010 & 2011 & Total \\
\hline Cao Bang & - & 1 & - & 1 & - & 3 & - & 2 & - & - & - & 7 \\
\hline Bac Kan & 8 & - & - & 11 & - & - & - & 2 & - & - & - & 21 \\
\hline Hoa Binh & 7 & 1 & - & 1 & - & 1 & - & - & - & - & - & 10 \\
\hline Son La & 24 & 6 & - & 5 & - & 43 & 8 & 1 & 19 & - & 126 & 232 \\
\hline Lai Chau & 15 & - & 3 & 1 & 6 & 26 & 12 & 18 & 5 & 12 & 5 & 103 \\
\hline Dien Bien & 1 & - & - & 3 & - & 3 & - & 2 & 25 & - & 42 & 76 \\
\hline Lao Cai & 27 & 34 & - & 59 & 13 & 18 & 89 & 2 & 12 & - & - & 254 \\
\hline Yen Bai & 4 & 31 & - & - & - & 3 & - & - & - & - & - & 38 \\
\hline Ha Giang & - & - & 8 & 16 & 1 & 14 & - & - & - & - & 13 & 52 \\
\hline Tuyen Quang & - & - & - & 10 & 11 & 30 & 4 & 2 & 3 & - & - & 60 \\
\hline Lang Son & - & - & - & 47 & 11 & 2 & 2 & - & - & - & - & 62 \\
\hline Phu Tho & - & 16 & 5 & - & 9 & - & - & - & - & - & - & 30 \\
\hline Vinh Phuc & - & - & - & - & 4 & - & - & - & - & - & - & 4 \\
\hline Ha Tay & - & - & - & 4 & - & 3 & 6 & - & - & - & - & 13 \\
\hline Ninh Binh & - & - & 4 & - & - & - & - & - & - & - & - & 4 \\
\hline Thanh Hoa & - & - & 8 & - & 3 & - & - & - & - & - & - & 11 \\
\hline Nghe An & - & 14 & 8 & 40 & - & - & 3 & - & - & - & - & 65 \\
\hline Ha Tinh & - & 4 & - & - & - & - & 2 & - & - & - & - & 6 \\
\hline Hue & - & 18 & - & 1 & - & - & - & - & - & - & - & 19 \\
\hline Kontum & - & - & - & 1 & - & 10 & - & - & - & - & - & 11 \\
\hline Dac Lac & - & - & - & 12 & - & - & - & - & - & - & - & 12 \\
\hline Total & 86 & 125 & 36 & 212 & 58 & 156 & 125 & 29 & 64 & 12 & 186 & 1090 \\
\hline
\end{tabular}

\subsection{Evaluation of genetic resources}

Recently, pests and many new strains of bacteria, fungi caused severe diseases in rice have been reported (Phan Huu Ton, et al., 2005, 2009). To create stable rice varieties with high quality and disease resistance, it is necessary to have a large number of materials and their properties as gene sources for breeding. Main important agronomic properties and traits such as glutinous rice, regular rice, type (Japonica, Indica, Javanica), light reaction, growth duration (short, medium and long) have been

analysed. By using DNA markers, the presence of genes for good quality and resistance traits was discovered. For example, resistance genes $\mathrm{Xa} 4, \mathrm{xa} 5$ and $\mathrm{Xa} 7$ for bacterial leaf blight (Phan Huu Ton, et al., 2005, 2009), Pi2 and Pita for brown planthopper (D.S. Brar, et al, 2009), Bph4 and Bph10 for blast (Miah G, et al., 2013, Nguyen Thi Lang, et al., 2010) $f g r$ for fragrant (Shu Xia Sun, et al., 2008) and $w x$ for amylose content (Myint Yi, et al., 2009; Ong, Y., et al., 2012) have been screened in all accessions. The results were shown in Table 2:

Table 2. Evaluation and characterization of rice genetic resources

\begin{tabular}{lclc} 
Criteria & Number of samples & Criteria & Number of samples \\
\hline Glutinous rice & 459 & Fragrant $(f g r)$ & 109 \\
Regular rice & 631 & Waxy $(w x)$ & 406 \\
Japonica & 496 & BLB $($ Xa 4$)$ & 238 \\
Indica & 543 & BLB (xa5) & 38 \\
Javanica & 51 & BLB (Xa7) & 217 \\
Light reaction & 135 & PBH (Bph4) & 28 \\
Short growth duration & 443 & PBH (Bph 10) & 30 \\
Medium growth duration & 512 & Blast (Pi2) & 43 \\
Long growth duration & 145 & Blast (Pi-ta) & 96
\end{tabular}

Analysis of 32 agronomic properties of 1090 accessions was revealed that there was a high level of diversity. There were 459 glutinous and 631 regular rice accessions. Results of subspecies classification showed that 496, 543

and 51 accessions were Japonica, Indica and Javanica, respectively. For growth duration, 3 different groups were classified in which 443, 512 and 145 accessions had short, medium and long growth duration, respectively (Table 2). 
Together with analysis of agronomic properties, DNA molecular markers were used to determine fragrant trait by the presence of the $f g r$ gene. Results showed that the fgr gene presented in 109 accessions. Comparison of the location of collected samples, it was surprised that ethic groups living in mountain areas tended to use fragrant rice. For quality trait, content of amylose is also an important agronomic trait of interest. In general, Vietnamese people and others in Asia countries prefer rice with low or medium amylose content. The gene for low content of amylose $w x$ was discovered in 406 accessions (Table 2).

Of rice diseases, bacterial leaf blight caused by Xanthomonas oryzae pv. oryzae is one of the most devastating diseases. It causes wilting of seedlings and yellowing and drying of leaves leading to vast destroy and lost of harvest. By using DNA markers, effective resistant genes $X a 4, x a 5, X a 7$ were identified in 238, 38 and 217 varieties, respectively. Two genes $P i 2$ and $P i$-ta were found in 43 and 96 out of 1090 collected accessions, respectively. Brown planthoppers was also a popular pests in Vietnam. They damage rice directly through feeding and also by transmitting viruses, notably rice ragged stunt virus and rice grassy stunt virus. Although information and specificity of resistance genes for brown planthopper are not very clear at the moment, two important genes, Bph4 and Bph10 have been used for evaluation of the resistance properties. The presence of Bph4 and Bph10 were identified in 28 and 30 accessions, respectively (Table 2 ).

\subsection{Utilization of rice genetic resources}

Since 2003, the genetic resources have been used as materials for breeding. New improved varieties with high productivity, quality and stable under unfavourable conditions have been selected. After 10 years, many new improved rice varieties were successfully created. For example, NV1, NV2, NV3 (glutinous rice) and TN13-5, T23 (regular rice) have been developed and widely accepted by farmers in many provinces in the north of Vietnam. These glutinous rice varieties were better than TK90, a common varieties cultivated widely at present. They have shorter growth duration, good quality, fragrant and suitable for both season crops in the north of Vietnam. These improved varieties had effective resistance genes to bacterial leaf blight, blast and brown planthoppers.

\subsection{Development of genetic resource}

At present, in some areas, local people are still using specialty rice varieties due to their advantage characters such as high quality, fragrant, stable under stress conditions and resistance to diseases and pests. These varieties are precious genetic resources for breeding. However, the degradation of these varieties is still ongoing. The reason for that is the local people do not know how to keep them properly after crops. Therefore, it is necessary to collect and restore these varieties. So far, 4 glutinous rice varieties Deo dang (Tuyen Quang), Pu De (Tuan Giao, Dien Bien), Ble chau and Khau Dao (Son La) have been col- lected and restored in the frame work of a on going project "Exploitation and development of 4 rice varieties, Deo dang, Pu De, Ble Chau and Khau Dao for north provinces" from 2012 to 2015 . At the moment, these varieties are cultivated widely as local specialties in provinces in the north of Vietnam.

\subsection{Strategies for genetic resource conservation by 2020}

The globalization, industrialization, tourism, services and exploration of population are reasons leading to the erosion and loss of genetic resources of plant, animal. In Vietnam, many local rice varieties are being lost because of the introduction of new improved varieties by agricultural extension activities. The introduction of improved varieties increased instant benefit for farmers because of high yield. However, the consequence of this process is the loss of local varieties. Being recognized the risks of erosion of genetic resource, strategies for conservation of rice genetic resources by 2020 were built. The first urgent task is investigation and collection of local rice varieties in all provinces of Vietnam to setup germplasm bank. Subsequently, the evaluation of agronomic properties of collected germplasm has to be implemented. DNA molecular markers should be used to screen effective resistant genes to diseases to build databases for Vietnamese rice varieties. Finally, enhancement of exploitation, restoration and development of local varieties for commercial products of local areas should be encouraged to bring the benefit for farmers in these areas.

\section{Conclusion and outlook}

So far, 1090 accessions of rice have been collected from local areas of Vietnam. Agronomical properties of these accessions have been characterized. DNA molecular markers were used to screen important genes for quality and resistance to diseases and pests. The obtained results are very necessary for long-term strategies including management and efficient utilization of the rice genetic resources. Through national breeding program, 3 new glutinous rice varieties NV1, NV2 and NV3 and 2 potential regular rice varieties TN13-5, T23 with high productivity, quality and disease resistance were created. In addition, 4 specialty glutinous rice varieties, Deo Dang, $\mathrm{Pu} \mathrm{De}$, Ble Chau and Khau Dao were restored for the north provinces of Vietnam.

The results suggested that the collection and conservation have to carry out at a large extent. The learned lesson from this study can be applied and expanded to other crops. In situ and ex situ conservation sites or protected areas should be formed under the government of authorized institutions. In addition, evaluation, utilization these genetic resources are required through national crop breeding programs. 


\section{References}

[1] D.S. Brar, P.S. Virk, K.K. Jena, G.S. Khush, 2009. Breeding for resistance to planthoppers in rice. Planthoppers: new threats to the sustainability of intensive rice production systems in Asia. Los Baños (Philippines): International Rice Research Institute. In Heong KL, Hardy B, (Ed.). 401-428.

[2] G. L. Denning, Vo Tong Xuan, 1994. Vietnam and IRRI: A partnership in rice research. Proceeding. ISBN 971-22-0067-1.

[3] M.Nakagahra, S. Miyazaki, D.A. Vaughan, 2000. Genebank Management of Crop Genetic Resources. Challenge to the Crisis of the Earth's Biosphere in the $21^{\text {st }}$ Century. 130-150.

[4] Miah G, Rafii MY, Ismail MR, Puteh AB, Rahim HA, Asfaliza R, Latif MA, 2013. Blast resistance in rice: a review of conventional breeding to molecular approaches. Mol Biol Rep. 40(3):2369-88.

[5] Myint Yi, Khin Than Nwe, Apichart Vanavichit, Witith Chai-arree, Theerayut Toojinda, 2009. Marker assisted backcross breeding to improve cooking quality traits in Myanmar rice cultivar Manawthukha. Field Crops Research 113 (2009) 178-186.

[6] Nguyen Thi Lang, Trinh Thi Luy, Pham Thi Thu Ha, Bui Chi Buu, 2010. Genotype analysis to blast disease in rice (Oryza sativa L.) in Mekong delta. Omonrice 17: 87-98.

[7] Nguyen Thi Lang, Bui Chi Buu, 2011. Rice genetic resource conservation and utilization in the Mekong delta. Omonrice 18: 22-33.

[8] Nguyen Thi Ngoc Hue, Luu Ngoc Trinh, 2007. Insitu conservation of plant genetic resources in Vietnam: Achievements and lessions learned. International Training Workshop. The Conservation and Utilization of Tropical/Subtropical Plant Genetic resource. 25-41.

[9] Nguyen Van Bo, 2002. Results and strategies for conservation of agricultural genetic resources. Results of conservation of agricultural genetic resources. Agriculture publishing house, Hanoi (in $\mathrm{Vi}$ etnamese)

[10] Ong, Y., Ngu, M. S., Parviz, F., Tilakavati, K. Wickneswari, R., 2012. Study on waxy gene polymorphism and amylose content of breeding lines derived from Oryza rufpogon x Oryza Sativa. Pertanika J. Trop. Agric. Sci. 35 (4): 833 - 842.

[11] Phan Huu Ton, Tong Van Hai, Nguyen Duc Bach, Nguyen Thi Lam Hai (2005). Application of DNA marker for identifying resistant genes to bacterial leaf blight of rice. Bull. Inst. Trop. Agr., Kyushu Uni. 28-1 (Special Issue): 15-24.

[12] Phan Huu Ton, Tong Van Hai, Nguyen Van Hung. 2009. Applied DNA molecular markers for screening of brown planthopper in Vietnamese rice varieties. National conference for plant diseases. 77-78 (in Vietnamese).

[13] Phan Huu Ton, Tong Van Hai, Tran Minh Thu, 2009. Investigation of rice genetic resources by DNA molecular markers for high quality rice breeding. National proceeding of Biotechnology, Hanoi. 427-431 (in Vietnamese).

[14] Shu Xia Sun, Fang Yuan Gao, Xian Jun Lu; Xian Jun $\mathrm{Wu}, \mathrm{Xu}$ Dong Wang, Guang Jun Ren, Hong Luo, 2008. Genetic analysis and gene fine mapping of aroma in rice (Oryza sativa L. Cyperales, Poaceae). Genetics and Molecular Biology, 31, 2, 532538.

[15] Thuy T. T. Nguyen, Nguyet M. T. Nguyen, Long H. Hoang, Naruto Furuya, Kenichi Tsuchiya, 2012. Genetic diversity in Vietnamese upland rice germplasm revealed by SSR markers. J. Fac. Agr., Kyushu Univ., 57 (2), 383-391.

[16] Yulin Jia, Zhonghua Wang, Pratibha Singh, 2002. Development of dominant rice blast $\mathrm{Pi}$-ta resistance gene markers. Crop Sci. 42:2145-2149. 